\title{
The Development of News Based Bioconservation Teaching Material Supplements to Embedding Environmental Awareness
}

\author{
Desianty Ariman $^{1 \bowtie}$, Dyah Rini Indriyanti ${ }^{2}$, Andreas Priyono Budi Prasetyo ${ }^{3}$ \\ ${ }^{1}$ Halmahera University, Indonesia \\ ${ }^{2}$ Biology, Mathematics and Natural Sciences Faculty, Universitas Negeri Semarang, Indonesia \\ ${ }^{3}$ Biology Education, Mathematics and Natural Sciences Faculty, Universitas Negeri Semarang, Indonesia
}

\begin{tabular}{l}
\hline Article Info \\
\hline Article History : \\
Received November 2019 \\
Accepted December 2019 \\
Published December 2020 \\
\hline Keywords: \\
Bioconservation, news \\
based teaching material, \\
environmental awareness \\
understanding.
\end{tabular}

Abstract

Teaching material supplement of News based bioconservation is compiled based on environmental news in the newspapaer in North Maluku. This research has purpose to identify the feasibility, readability and effectiveness of the news based bioconservation teaching material supplements. This study applied a Research and Development (R\&D) approach. The subjects in this study were the fifth grade students of SD Inpres Aru Irian and SD BPD Falila, Morotai Island Regency. The data collection technique was carried out using expert validation questionnaires, student response questionnaires and cognitive tests. The data obtained by expert validation showed a score of $90.79 \%$, indicated that the news based bioconservation teaching material supplement was very suitable to be used in the learning. The effectiveness of teaching material supplements was determined based on the classical completeness and $\mathrm{N}$-gain values. The classical completeness of students in the pretest test was $29 \%$, meanwhile, in the posttest test was $86 \%$. Based on the classical completeness requirements $\geq 80 \%$, indicated that students completed classically. The $\mathrm{N}$-gain test obtained was 0.75 with high criteria or classified g $\geq 0.7$, it was concluded that the teaching material supplement of news based bioconservation teaching was effective in improving student learning outcomes. The understanding of environmental awareness was obtained using an environmental awareness questionnaire, the criteria obtained were high with a mean score of $73.88 \%$. Based on the result of the study, then, it can be concluded that teaching material supplement of news based bioconservation is appropriate to be used as teaching materials in the learning and effectively embedding the student learning outcomes and the understanding of environmental awareness.

(C) 2020 Universitas Negeri Semarang

\footnotetext{
correspondence:

Halmahera University

Jl. Raya Wari, Wari Ino, Tobelo, Kabupaten Halmahera Utara,

Maluku Utara, Indonesia

E-mail: desiantyariman88@gmail.com
}

p-ISSN 2252-6412

e-ISSN 2502-4523 


\section{INTRODUCTION}

Morotai Island is one of the outer islands in Indonesia, this causes the lack of access to Morotai Island which has an impact on various fields, one of which is education in the form of limited teaching materials. Schools on Morotai Island accounted for $60 \%$ of them still using the KTSP textbook (Morotai Island Education and Culture Office, 2018). The implementation of conservation oriented education in schools requires appropriate teaching materials. The use of conservation-oriented teaching materials can increase one's interest in learning and taking wise actions in increasing students' knowledge and attitudes (Dimopoulos et al., 2009). The lack of community awareness of the environment has resulted in the increased levels of environmental damage (Rarasandy et al., 2013).

The Ministry of National Education (2008) states that teaching materials have several functions, namely as (1) guidelines for teachers in directing the learning process, (2) guidelines for students as well as being a part that must be learned or mastered, and (3) as an evaluation tool for learning achievement. Teaching materials play an important role in a learning process, which is as a medium in the delivery of information (Paramita \& Rusilowati, 2016), (Kurniasih \& Sani, 2014). The supplements of teaching materials that are developed are not only useful for students, but also beneficial for teachers. The selection of appropriate teaching materials can produce the maximum learning.

The results of observations and interviews conducted with the fifth-grade teachers of SD Inpres Aru Irian and SD BPD Falila, South Morotai Subdistrict regarding Natural Science learning show the results that supplementary news based bioconservation teaching materials are not yet available in these schools. Teaching materials used by teachers in the learning process are only in the form of textbooks obtained from publishers.

The initial survey of students in Aru Irian Elementary School and Falila BPD Elementary School showed that only a small number of students carried out environmentally friendly actions such as, (1) maintaining cleanliness, (2) not littering, (3) walking to school (4) ) reduce paper usage. These results were supported by the results of interviews with grade $\mathrm{V}$ teachers at $\mathrm{SD}$ Inpres Aru Irian and SD BPD Falila showing data that at the school most students still did not really understand the importance of protecting the environment. Bioconservation oriented teaching materials that are not yet available make the learning process of teachers only use books provided by the government.

Conservation biology is an effort to maintain the survival of living things and stop the loss of biodiversity (Champbell \& Reece, 2008). Leksono et al., (2015) research results in conservation biology teaching materials can help students understand the material, improve biodiversity process skills and care for the environment. Similar research by Sukarjita et al., (2015), and Indriawati et al., (2016) learning science using a contextual approach, and multimedia effectively improve students' knowledge about the environment.

Textbooks written based on local conditions of an area are able to make a high contribution to biodiversity conservation and can improve communication skills (Primack et al., 2013), (Rahayu \& Sudarmin, 2015). Similar research by Yanti et al., (2015) shows that learning using a contextual approach nearby the students can foster the literacy and environmental awareness. Environmental awareness is a person's ability to realize the relationship between human activities and the surrounding environment to create a safe and healthy environment (Laksmi, 2015).

News based learning is an approach in learning that uses news from newspapers. News based learning provides an opportunity for students to understand the news contained in newspapers. News-based learning models can improve scientific literacy, critical thinking, and student creativity (Kartini et al., 2018). Contextbased science learning by utilizing newspaper news contributes and increases motivation in achieving the learning objectives (Khun \& Muller, 2014).

Based on the background, the formulations of the problem in this research are (1) how is the feasibility of news based bioconservation teaching material supplements? (2) how is the effectiveness of using news based bioconservation teaching material supplements on the students learning outcomes? (3) how effective is the use of news 
based bioconservation teaching supplements to improve the students' environmental awareness?

The purpose of this study was to identify the feasibility and effectiveness of the news based bioconservation teaching materials supplement for the inculcation of environmental awareness of Morotai Island elementary school students.

This research provide the following benefits: (1) increase the learning resources, (2) improve the student learning outcomes, (3) increase the understanding of environmental awareness of students to maintain and preserve the environment.

\section{METHOD}

The research method used in this study was the Research and Development (R\&D) method to produce and test the effectiveness of product. The steps of the study are presented in Figure 1.

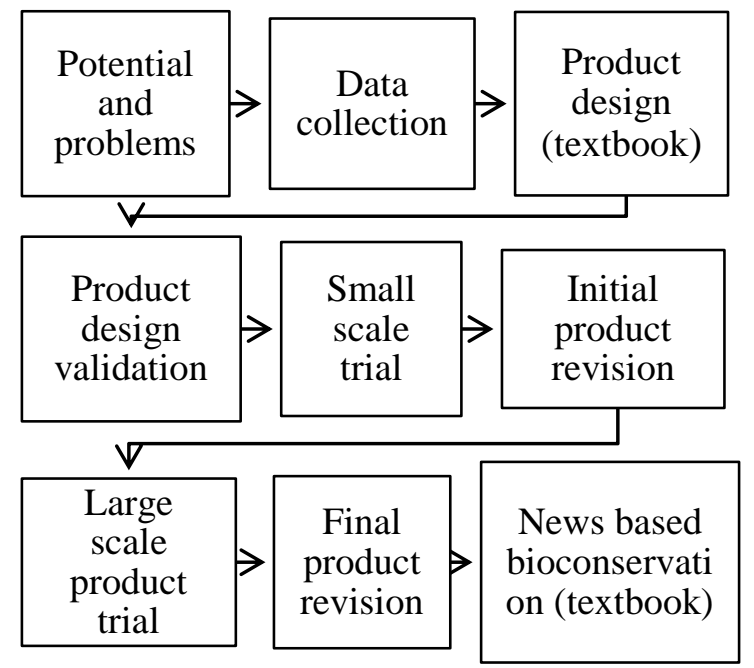

Figure 1. The Steps of The Study Using R\&D.

The subjects in this study were grade $\mathrm{V}$ students of SD Inpres and SD BPD Falila in the second semester of 2019/2020, with the total number of 28 students. The instruments used in the study were expert validation sheets, test sheets, and environmental awareness questionnaire sheets. The instruments were validated by experts before applying it in the study.

The learning tool that will be used were tested using validity (construct validity, content validity, and item validity). The data collection technique used in this study were compiled based on the formulation of the problem under study:

the validation sheet was used to obtain data about the feasibility of the teaching material supplements, the student response questionnaire was used to obtain data on the readability of the teaching materials, the test sheets were used to obtain the data on the learning outcomes. Then, pretest and posttest, environmental awareness understanding questionnaire sheets were used to obtain data about the understanding of environmental awareness of students after using the teaching material supplements.

\section{RESULTS AND DISCUSSION}

The results of the validation of the news based bioconservation of teaching materials supplement can be seen in the following Table 1

Table 1. The Result of Feasibility Test of News Based Bioconservation Teaching Supplements by experts

\begin{tabular}{clll}
\hline Validator & Institution & $\begin{array}{l}\text { Score } \\
(\%)\end{array}$ & Criteria \\
\hline 1 & $\begin{array}{l}\text { Lecturer of } \\
\text { UNNES }\end{array}$ & 90.79 & Very feasible \\
2 & $\begin{array}{l}\text { Lecturer of } \\
\text { UNNES }\end{array}$ & 89.47 & Very feasible \\
3 & $\begin{array}{l}\text { SD Inpres Aru } \\
\text { Irian }\end{array}$ & 92.11 & Very feasible \\
Average & & 90.79 & Very feasible \\
\hline
\end{tabular}

Based on the results of the feasibility test of teaching materials supplement obtained an average percentage of $90.79 \%$ with a very feasible criteria, therefore, it can be interpreted that the news based bioconservation teaching material supplements can be used for the learning. The results of the acquisition of feasible criteria are in accordance with the results of research conducted by (Zainuddin et al., 2012; Izzati et al., 2013; Kurniawati, 2013; Septianu et al., 2014) which states that after conducting the validation stage, the teaching materials developed are feasible to be used as a learning medium.

The results of the readability analysis of news based bioconservation teaching material supplements are presented in the following Table 2 . 
Table 2. Results of Analysis of Redability of Teaching Material Supplement

\begin{tabular}{ll}
\hline Assessment Criteria & Score of Readability (\%) \\
\hline Material feasibility & 88.13 \\
Language & 83.48 \\
Presentation & 85.04 \\
Graphics & 87.95 \\
Average & 86.15 \\
\hline
\end{tabular}

The average score of the readability analysis of teaching material supplements was $86.15 \%$. The score obtained in the form of the feasibility of the material was $88.13 \%$, the language was $83.48 \%$, the presentation was $85.04 \%$, and graphic was $87.95 \%$ had fulfilled the evaluation criteria. Based on the readability score, it can be concluded that the news based bioconservation teaching material supplement developed can be used for the learning using the theme of "environment is our best friend" (lingkungan sahabat kita) in the fifth grade elementary school of Morotai Island.

The effectiveness of news based bioconservation teaching material supplements on "environment is our best friend" (lingkungan sahabat kita) themes was determined based on the value of (a) classical completeness, (b) N-gain. The results of the analysis of the percentage of students' mastery learning are presented in th following Figure 2.

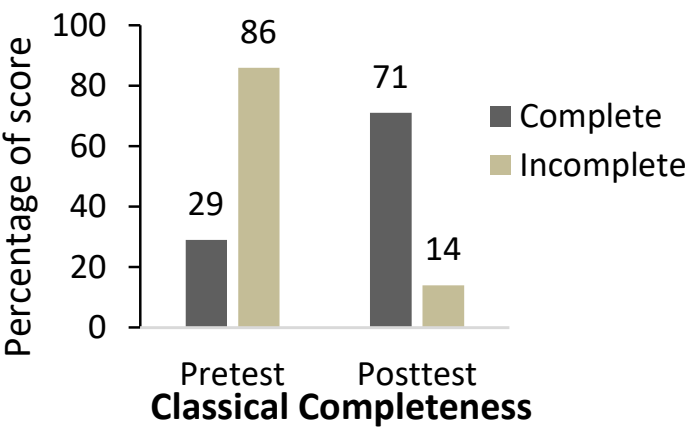

Figure 2. Score of The Completeness of Students Learning Outcomes.

The classical completeness of student learning outcomes in the pretest test were $29 \%$, meanwhile, the posttest test were $86 \%$. Based on the classical completeness requirements $\geq 80 \%$, the cognitive assessment results of students were completed classically. These results are consistent with the research by (Estiwi et al., 2015; Istikomah et al., 2013) which states that the development of findings-based learning tools for science understanding in Kindergarten B Children is said to be effective with the acquisition of an average score of learning outcome of $83 \%$.

The cognitive learning outcomes of students were obtained from the results of the pretest and posttest. The student cognitive learning outcomes after learning has increased. The recapitulation of the pretest and posttest of learning outcomes conducted is presented in the following Table 3 .

Table 3. Score of N-Gain of Students Learning Outcome

\begin{tabular}{llll} 
Score & Average & Maximum & Minimum \\
\hline Pretest & 32.75 & 50 & 9 \\
Postest & 83.75 & 88 & 79 \\
N-gain & 0.75 & 0.87 & 0.64 \\
\hline
\end{tabular}

Based on the $\mathrm{N}$-gain analysis of student learning outcomes obtained a score of 0.75 , which are in the high criteria $(<\mathrm{g}>\geq 0.7)$. It can be concluded that the news based bioconservation teaching materials supplements using theme of "environment is our best friend" (lingkungan sahabat kita) was effectively improve the learning outcomes of students in SD Inpres Aru Irian and SD BPD Falila.

The analysis of environmental awareness understanding was obtained by using a student questionnaire response sheet. The results of the environmental awareness analysis are presented in the following Table 8 .

Table 8. The Analysis of the Understanding of Environmental Awareness

\begin{tabular}{lll}
\hline Respondent & Total Score & Score (\%) \\
\hline SD BPD Falila & 146 & 74.87 \\
SD Inpres Aru Irian & 164 & 72.89 \\
Average & & 73.88 Good \\
\hline
\end{tabular}

The understanding of students' environmental awareness based on table 7, at SD BPD Falila was $74.87 \%$ and SD Inpres Aru Irian was $72.89 \%$, therefore, the average percentage score obtained was $73.88 \%$ with good criteria.

\section{CONCLUSION}

Based on the result of the study, it can be concluded that the development of the news based bioconservation teaching material supplements using the theme of "environment is our best 
friend" (lingkungan sahabat kita) is appropriate to be used as teaching materials in the learning and effectively embedding the students learning outcomes and their understanding of environmental awareness.

\section{REFERENCES}

Campbell, N. A. \& Reece, J. B. (2008). Biologi Edisi ke 8 Jilid 3. (Ahli bahasa: Damaring Tyas Wulandari). Jakarta: Erlangga

Depdiknas. (2008). Panduan Pengembangan Bahan Ajar. Jakarta: Depdiknas.

Dimopoulos, D. I., Paraskevopoulos, S., \& Pantis, J. D. (2009). Planning Educational Activities and Teaching Strategies on Contructing a Conservation Educational Module. International Journal of Environmental and Science Education, 4 (4), 351-364.

Dinas Pendidikan dan kebudayaan Kabupaten Pulau Morota. (2018)

Estiwi, E., Raharjo, T. J., \& Syamwil, R. (2015). Pengembangan Model Pembelajaran Tematik Berbasis Discovery Learning Untuk Memperkenalkan Konsep Sains. Journal of Primary Education (JPE) 4 (1) 10-14.

Indriawati, A., Susilowati, S. M. E., \& Supardi, K. I. (2016). Pembelajaran Berbasis Masalah dengan Bahan AJar Berorientasi Sumberdaya Perairan Terhadap Karakter Peduli Lingkungan dan Hasil Belajar IPA. Journal of Primary Education, $5(2)$.

Istikomah., Hartono., \& Rusilowati A. (2013). Pengembangan Perangkat Pembelajaran Metode Discovery Learning Untuk Pemahaman Sains Pada Anak TK B. Jurnal of Primary Education 2 (2), 71-76

Izzati, N., Hindarto, N., \& Pamelasari, S.D. (2013). Pengembangan Modul Tematik dan Inovatif Berkarakter Pada Tema Pencemaran Lingkungan Untuk Siswa Kelas VII SMP. Jurnal Pendidikan IPA Indonesia 2(2), 183-188.

Kartini, I., Prasetyo, A. P. B., \& Iswari, R. S. (2018). Effect of use of News-Based Science Teaching on Al Madani Pesantren Student's Literacies. Journal of Innovative Science Education, 7(2), 184189.

Khun, J.. \& Muller A. (2014). Context-Based Science Education by Newspaper Story Problems: A Study on Motivation and Learning Effects. Perspectives in Science, 2, 5-21.

Kurniasih, I., \& Sani, B. (2014). Panduan Membuat Bahan Ajar Buku Teks Pelajaran Sesuai dengan Kurikulum 2013. Surabaya: Kata Pena.
Kurniawati Amaliya. (2013). Pengembangan Bahan Ajar Terpadu Tema Letusan Gunung Berapi Kelas VII di SMP Negeri 1 Kemal. Jurnal Pendidikan Sains e-Pensa. Vol. 01 (01), 42-46.

Laksmi, A. D. (2015). Peran Sikap dalam Memediasi Pengaruh Kesadaran Lingkungan Terhadap Niat Beli Produk Ramah Lingkungan. E-Jurnal Manajemen Unud, 4 (7), 1902-1917.

Leksono, S. M., Syachruroji, A., \& Marianingsih, P. (2015). Pengembangan Bahan Ajar Biologi Konservasi Berbasis Etnopedagogi. Jurnal Pendidikan, 45 (2), 168-183.

Paramitha, A. D., Rusilowati, A., \& Sugianto. (2016). Pengembangan Bahan Ajar Berbasis Literasi Sains Materi Suhu dan Kalor. Jurusan Fisika Fakultas Matematika dan Ilmu Pengetahuan Alam.

Primack, R. B., Paudel, P. K., \& Bhattarai, B. P. (2013). Conservation Biology: A Primer for Nepal. Dreamland Publication: Kathmandu, Nepal.

Rahayu, W. E., \& Sudarmin. 2015. Pengembangan Modul IPA Terpadu Berbasis Etnosains Tema Energi dalam Kehidupan untuk Menanamkan Jiwa Konservasi. Unnes Science Education Journal, 4(2).

Rarasandy, L., Indriyanti, D.R., \& Santosa K. (2013). Pembelajaran Biologi Mengarah Pada Penanaman Karakter Peduli Lingkungan pada Materi Pengelolaan Lingkungan. Lembaran Ilmu Kependidikan, 42(2), 129-136.

Septianu Edo, Sudarmin., \& Widiyatmoko, Arif. (2014). Pengembangan Modul IPA Terpadu Tema Perubahan Zat Berbasis Discovery Untuk Meningkatkan Keterampilan Generik dan Hasil Belajar Siswa. Unnes Science Education Journal (USEJ). (3), 53-661.

Sugiyono. (2016). Metodologi Penelitian dan Pengembangan (2nd ed.). Bandung: Alfabeta.

Sukarjita, I.W., Ardi, M., Rachman, A., Supu, A., \& Dirawan, G.D. (2015). The Integration of Environmental Education in Science Materials by Using MOTORIC Learning Model. Internasional Education Studies, 8(1), 152-159.

Yanti, E., Haryani, S., \& Supardi, K. I. (2015). Pengembangan Bahan AJar Koloid Bermuatan Karakter Berbasis Discovery-Inquiry untuk Meningkatkan Keterampilan Berkomunikasi Siswa SMA. Journal of Innovative Science Education, 4 (1), 1-9.

Zainuddin, Mustikawati., \& Suyidno. (2012). Pengembangan Modul Fisika Bumi-Antariksa untuk Meningkatkan Prestasi Belajar Mahasiswa Prodi Pendidikan Fisika FKIP Unlam. Jurnal Vidya Karya, 1 (1): 63-70. 